\title{
Pensonomonoor
}

2017, vol. 78, 40-50

http://dx.doi.org/10.12657/denbio.078.005

\author{
Piotr Kosiński, Adam Boratyński, Andreas Hilpold
}

\section{Taxonomic differentiation of Salix retusa agg. (Salicaceae) based on leaf characteristics}

\author{
Received: 1 February 2017; Accepted: 20 April 2017
}

\begin{abstract}
The complex of Salix retusa includes S. retusa s.s., S serpyllifolia and S. kitaibeliana, small, prostrate willows occurring in the subalpine and alpine vegetation belts of the mountains of Central Europe: the Pyrenees, Alps, Apennines, Dynaric Alps, Carpathians and Rila. The systematic positions of these taxa are not fully resolved and are still disputed. The aim of the present study was to biometrically verify differences in leaf characteristics between these taxa.

Material was collected from 47 populations, each represented by $25-52$ individuals (33 on average). The study was based on 14 leaf morphological characters measured from scans using Win Folia software. The principal component analysis (PCA), Ward's agglomeration method, the $K$-means cluster analysis (K-MCA) and Kruskal-Wallis tests were applied to verify the relationships between taxa and their populations.

Differences between average leaf characteristics of S. retusa s.S., S. serpyllifolia and S. kitaibeliana were detected. The Pyrenean populations of S. retusa s.s. appeared more similar to S. serpyllifolia. Within the Alpine populations of S. serpyllifolia, several individuals resembling S. retusa s.s. were detected, and vice versa, within populations of $S$. retusa s.s., and there were also individuals similar to S. serpyllifolia. The controversial S. kitaibeliana was found to be typical of the Tatra Mountains.

The results support close taxonomic relations, but also the separate status of S. retusa, S. serpyllifolia and S. kitaibeliana. The differences between them are mainly of a quantitative nature.
\end{abstract}

Keywords: oreophytes, alpine plants, biometrics, morphology, systematics

Addresses: P. Kosiński, Poznań University of Life Sciences, Faculty of Horticulture and Landscape Architecture, Department of Botany, Wojska Polskiego 71c, PL-60-625 Poznań, Poland, e-mail: kosinski@up.poznan.pl

A. Boratyński, P. Kosiński, Institute of Dendrology, Polish Academy of Sciences, Parkowa 5, 62-035 Kórnik, Poland

A. Hilpold, Institute for Alpine Environment, European Academy of Bozen/Bolzano, Eurac Research, Drususallee 1, 39100 Bolzano/Bozen, Italy

\section{Introduction}

The complex of Salix retusa L. includes S. retusa s.s., S. serpyllifolia Scop. and S. kitaibeliana Willd. (Rechinger, 1964; Dostál, 1989) (Supplementary Figs 1-4). Salix serpyllifolia has generally been treated as a separate species (e.g. Rechinger, 1957, 1964; Jalas \& Suominen, 1976; Martini \& Paiero, 1988; Skvortsov, 1999; Hörandl et al., 2002, and literature cited herein). However, Salix kitaibeliana has not only been considered a separate species, mostly in the local floras of the Carpathians (e.g. Szafer, 1921; Pawłowski, 
1956; Koblížek, 2006; but also Rechinger, 1964), but it has also been treated as a subspecies, S. retusa subsp. kitaibeliana (Willd.) Jáv. (Baldie, 1952), and variety, S. retusa var. kitaibeliana (Willd.) Rchb., and finally, most frequently, as a synonym of $S$. retusa (e.g. Skvortsov, 1999; Mirek et al., 2002; Danilik, 2009).

The differences between these three taxa, independent of their systematic rank, are predominantly quantitative. Salix serpyllifolia has significantly smaller organs, while S. kitaibeliana has larger organs than S. retusa s.s. The leaves of S. serpyllifolia are less than half as long and wide as those of $S$. retusa s.s. (Rechinger, 1964) and the whole shrub is more compact, resembling 'miniaturised' S. retusa s.s. (Skvortsov, 1999). Salix retusa s.s. and S. serpyllifolia sometimes grow side by side in the Alps and usually the specimens can be easily distinguished in the field (Martini \& Paiero, 1988; Skvortsov, 1999).

The leaves of S. kitaibeliana are more or less twice as long and broad as those of $S$. retusa, and their apex can sometimes be rounded, obtuse or even acute, not retuse (Rechinger, 1964; Dostál, 1989). However, in nature, many intermediate specimens between $S$. retusa s.s. and S. kitaibeliana can be observed, and the differences between these taxa are unclear (Pawłowski, 1956; Zieliński, 1977; Hardig et al., 2000). This has been the main reason for a lack of recognition between $S$. retusa and S. kitaibeliana (e.g. Zieliński, 1977; Skvortsov, 1999). The latter two taxa have been reported from different local environmental conditions in the Tatra Mountains: S. retusa s.s. is found on calcium-containing substrates, while $S$. kitaibeliana is found on siliceous rocks, mainly in moist places close to water sources and streams (Pawłowski, 1972; Dostál, 1989; Koblížek, 2006).

Salix retusa s.s. occurs in the mountains of Central Europe; from the Pyrenees in the West to the East Carpathians in the East and to the Central Apennines and Rila in the South. Salix serpyllifolia is considered as an Alpine subendemic species with only single localities in the Balkans, while the range of S. kitaibeliana is limited to the Carpathians (Pawłowski, 1972; Jalas \& Suominen, 1976; Zając \& Zając, 2009). All three taxa grow mainly in alpine zone, and sometimes in subalpine zone (Pawłowski, 1956, 1972; Baldie, 1967; Horvat et al., 1984; Ozenda, 1988; Martini \& Paiero, 1988; Villar et al., 1997; Skvortsov, 1999; Hörandl et al., 2002; Ozenda \& Borel, 2003; Zając \& Zając, 2009). Their geographic distributions are discontinuous, divided into several parts depending on sufficient altitude of mountain massifs (e.g. Nagy et al., 2003; Ronikier, 2011). The populations of S. retu$s a$ s.s. in the Alps are isolated from the Carpathian, Balkan and Apennine ones (see Jalas \& Suominen, 1976, figs 208 and 209). In addition, large distances separate populations within the Carpathians and Balkans. The distances between the Pyrenean, Alpine,
Balkan and Carpathian ranges of S. retusa s.s. could be a reason for further morphological differentiation of this species, which has not been verified until now. The same may also have occurred for S. retusa and S. serpyllifolia in the Alps, as genetic break zones have been detected between West and East Alpine populations among species of the Alpine vegetation belts (Thiel-Egenter et al., 2011), and montane and subalpine tree species (Mosca et al., 2012).

Taking into account the above, we hypothesise that (1) morphological differences between leaf samples representing particular taxa of $S$. retusa group will be detected, (2) the Pyrenean, Alpine, Balkan and Carpathian populations of $S$. retusa s.s. will be morphologically different, (3) the populations of $S$. retusa s.s. and S. serpyllifolia sampled from the western versus eastern Alps could be morphologically different and (4) the populations of $S$. retusa s.l. (i.e. including S. kitaibeliana) sampled from calcareous sites will be morphologically different from those sampled from substrata of siliceous origin. The aim of the present study is to verify the above-mentioned hypotheses using biometrical analyses of leaves, organs most frequently found in herbarium collections, and thus validate the basis for distinguishing between S. retusa s.s., S. serpyllifolia and S. kitaibeliana.

\section{Material and methods}

\section{Plant material collection and measurement procedure}

Material was sampled from natural populations of S. retusa s.l. and S. serpyllifolia; S. kitaibeliana was not distinguished from $S$. retusa s.s. during sampling. Every individual was categorised in the field according to morphological characteristics accepted as taxonomically important for distinguishing between S. retusa s.s. and S. serpyllifolia (Rechinger, 1957, 1964; Skvortsov, 1999). Well-developed, uninjured leaves were collected from the central part of vegetative shoots. In order to avoid sampling the same genet more than once, sampled plants were separated by at least $10 \mathrm{~m}$, as willows from the $S$. retusa group reproduce vegetatively by sprout rooting (the distance was sometimes smaller when neighbouring individuals were of opposite sex) (e.g. Rechinger, 1957; Hörandl et al., 2002; Kobližek, 2006). The 25-52 individuals (33 on average) from 15 populations of S. serpyllifolia and 32 populations of $S$. retusa s.l. (including possible S. kitaibeliana) were sampled (Table 1). In the Alps, S. retusa s.s. and S. serpyllifolia were sampled in eight cases in the same location. Every individual was represented by 5 leaves, which were dried in herbarium presses after sampling and stored in dry conditions until measurement. 
Table 1. Sampled populations of Salix retusa agg.; $\mathrm{N}$ - number of sampled individuals

\begin{tabular}{|c|c|c|c|c|c|c|}
\hline Code & Locality & $\mathrm{N}$ & $\begin{array}{c}\text { Longitude } \\
\left.{ }^{\circ}\right]\end{array}$ & $\begin{array}{c}\text { Latitude } \\
{\left[{ }^{\circ}\right]}\end{array}$ & $\begin{array}{c}\text { Altitude } \\
{[\mathrm{m}]}\end{array}$ & Collector \\
\hline A1 & France, Alps, Maritime Alps, Auron & 30 & 6.907 & 44.208 & 2268 & $\mathrm{PK}, \mathrm{AH}$ \\
\hline $\mathrm{A} 2 *$ & France, Alps, Maritime Alps, Mt Bonette & 35 & 6.833 & 44.335 & 2542 & $\mathrm{PK}, \mathrm{AH}$ \\
\hline A3 & France, Alps, Cottian Alps, Col de Vars & 30 & 6.685 & 44.548 & 2395 & $\mathrm{PK}, \mathrm{AH}$ \\
\hline $\mathrm{A} 4^{*}$ & France, Alps, Cottian Alps, Col d'Izoard & 35 & 6.737 & 44.815 & 2293 & $\mathrm{PK}, \mathrm{AH}$ \\
\hline A5 & France, Alps, Cottian Alps, Col d'Izoard & 30 & 6.735 & 44.820 & 2378 & $\mathrm{PK}, \mathrm{AH}$ \\
\hline A6 & France, Alps, Graian Alps, Col du Galibier & 30 & 6.403 & 45.062 & 2599 & $\mathrm{PK}, \mathrm{AH}$ \\
\hline $\mathrm{A} 6^{*}$ & France, Alps, Graian Alps, Col du Galibier & 34 & 6.403 & 45.062 & 2599 & $\mathrm{PK}, \mathrm{AH}$ \\
\hline A7a* & France, Alps, Graian Alps, Col de l'Iseran & 35 & 7.042 & 45.401 & 2591 & $\mathrm{PK}, \mathrm{AH}$ \\
\hline A7b* & France, Alps, Graian Alps, Val d'Isère & 33 & 7.010 & 45.438 & 2447 & $\mathrm{PK}, \mathrm{AH}$ \\
\hline A8 & France, Alps, Graian Alps, Little St Bernard Pass & 30 & 6.876 & 45.665 & 2193 & $\mathrm{PK}, \mathrm{AH}$ \\
\hline $\mathrm{A} 8^{*}$ & France, Alps, Graian Alps, Little St Bernard Pass & 32 & 6.876 & 45.665 & 2193 & $\mathrm{PK}, \mathrm{AH}$ \\
\hline A9 & Switzerland, Alps, Bernese Alps, Crans-Montana, las Violetes & 30 & 7.498 & 46.342 & 2233 & PK \\
\hline $\mathrm{A} 9^{*}$ & Switzerland, Alps, Bernese Alps, Crans-Montana, las Violetes & 31 & 7.498 & 46.342 & 2233 & PK \\
\hline A10* & Switzerland, Alps, Bernese Alps, Simplon Pass, Mt Hübschhorn & 34 & 8.046 & 46.248 & 2167 & PK \\
\hline A11 & Switzerland, Alps, Bernese Alps (Uri Alps), Furka Pass, Rhone Glacier & 30 & 8.389 & 46.579 & 2384 & $\mathrm{PK}, \mathrm{AH}$ \\
\hline A $11^{*}$ & Switzerland, Alps, Bernese Alps (Uri Alps), Furka Pass, Rhone Glacier & 33 & 8.389 & 46.579 & 2384 & $\mathrm{PK}, \mathrm{AH}$ \\
\hline A12* & Switzerland, Alps, Bernese Alps (Uri Alps), Oberalp Pass & 25 & 8.673 & 46.660 & 2075 & $\mathrm{PK}, \mathrm{AH}$ \\
\hline A13* & Switzerland, Alps, Pennine Alps, Great St. Bernard Pass & 35 & 7.162 & 45.868 & 2401 & $\mathrm{PK}, \mathrm{AH}$ \\
\hline A14 & Switzerland, Alps, Glarus Alps, Pizol & 30 & 9.434 & 46.980 & 2215 & PK \\
\hline A $14^{*}$ & Switzerland, Alps, Glarus Alps, Pizol & 33 & 9.434 & 46.980 & 2215 & PK \\
\hline A15 & Switzerland, Alps, Western Rhaetian Alps, Flüela Pass & 30 & 9.941 & 46.752 & 2398 & $\mathrm{PK}, \mathrm{AH}$ \\
\hline A16 & Switzerland, Alps, Western Rhaetian Alps, Fuorn Pass (Ofen Pass) & 30 & 10.293 & 46.639 & 2157 & $\mathrm{PK}, \mathrm{AH}$ \\
\hline A17 & Italy, Alps, Sarntaler Alpen, Königsangerspitze (Monte Pascolo) & 30 & 11.581 & 46.708 & 2318 & $\mathrm{PK}, \mathrm{AH}$ \\
\hline A $17^{*}$ & Italy, Alps, Sarntaler Alpen, Königsangerspitze (Monte Pascolo) & 32 & 11.581 & 46.708 & 2318 & $\mathrm{PK}, \mathrm{AH}$ \\
\hline A18 & Italy, Alps, Dolomites, Rosengarten & 30 & 11.617 & 46.416 & 2236 & $\mathrm{PK}, \mathrm{AH}$ \\
\hline A18* & Italy, Alps, Dolomites, Rosengarten & 31 & 11.617 & 46.416 & 2236 & $\mathrm{PK}, \mathrm{AH}$ \\
\hline A19 & Italy, Alps, Dolomites, Rolle Pass & 30 & 11.795 & 46.308 & 2267 & $\mathrm{PK}, \mathrm{AH}$ \\
\hline A20 & Italy, Alps, Adamello-Presanella Alps, Mt Presanella & 30 & 10.580 & 46.239 & 2573 & PK \\
\hline A $20^{*}$ & Italy, Alps, Adamello-Presanella Alps, Mt Presanella & 35 & 10.580 & 46.239 & 2573 & PK \\
\hline $\mathrm{A} 21$ & Italy, Alps, Adamello-Presanella Alps, Croce Domini Pass & 30 & 10.414 & 45.915 & 2086 & $\mathrm{PK}, \mathrm{AH}$ \\
\hline Ap1 & Italy, Apennines, Abruzzi Apennines, Corno Grande & 30 & 13.563 & 42.460 & 2473 & PK \\
\hline Ap2 & Italy, Apennines, Sibillini Mts, Monte Vettore & 30 & 13.281 & 42.822 & 2362 & PK \\
\hline $\mathrm{B} 1$ & Bulgaria, Rila Mts, Rila Mts, Mt Mramorec & 50 & 23.472 & 42.101 & 2567 & PK \\
\hline B2 & Albania, Korab Massif, Korab Massif, Mt Korab & 37 & 20.547 & 41.783 & 2596 & PK \\
\hline P2 & Spain, Western Pyrenees, Bisaurín & 39 & $-0,635$ & 42,788 & 2559 & $\mathrm{PK}, \mathrm{AH}$ \\
\hline P4 & Spain, Western Pyrenees, Tendeñera Mts, Mt Sabocos & 30 & $-0,263$ & 42,687 & 2213 & $\mathrm{PK}, \mathrm{AH}$ \\
\hline P5 & Spain, Western Pyrenees, Pyrenees of Huesca, Bujaruelo valley & 36 & $-0,077$ & 42,702 & 2049 & $\mathrm{PK}, \mathrm{AH}$ \\
\hline $\mathrm{R} 1$ & Romania, Southern Carpathians, Bucegi Mts, Mt Jepii Mici & 32 & 25.483 & 45.410 & 2079 & PK \\
\hline $\mathrm{R} 2$ & Romania, Southern Carpathians, Făgăraş Mts, Balea Lake & 30 & 24.616 & 45.600 & 2177 & PK \\
\hline R3 & Romania, Southern Carpathians, Parâng Mts, Mt Cârja & 30 & 23.521 & 45.365 & 2263 & PK \\
\hline $\mathrm{R} 4$ & Romania, Eastern Carpathians, Rodna Mts, Mt Pietrosul Rodnei & 30 & 24.638 & 47.595 & 2177 & PK \\
\hline $\mathrm{T} 1$ & Slovakia, Western Carpathians, High Tatras, Vyšné Žabie pleso (tarn) & 52 & 20.091 & 49.192 & 1723 & PK, PG \\
\hline $\mathrm{T} 2$ & Slovakia, Western Carpathians, High Tatras, Zelené Kačacie pleso (tarn) & 31 & 20.116 & 49.176 & 1595 & PK, PG \\
\hline T3 & Poland, Western Carpathians, Western Tatras, Mt Beskid & 35 & 19.980 & 49.235 & 1950 & PK \\
\hline $\mathrm{T} 4$ & Poland, Western Carpathians, Western Tatras, Mt Jarząbczy Wierch & 30 & 19.795 & 49.200 & 1737 & PK, PG \\
\hline T5 & Slovakia, Western Carpathians, High Tatras, Sedlo pod Sviš̌tovkou Pass & 45 & 20.236 & 49.205 & 1920 & PK, PG \\
\hline $\mathrm{T} 8$ & Poland, Western Carpathians, High Tatras, Black Lake below Mt Rysy & 31 & 20.079 & 49.187 & 1575 & PK \\
\hline
\end{tabular}

Asterix $\left({ }^{*}\right)$ - populations of S. serpyllifolia; PK - Piotr Kosiński, AH - Andreas Hilpold, PG - Piotr Górski.

Each leaf was characterised using 14 characteristics: 7 measured (Fig. 1B) and a further 7 resulting from calculations (Table 2). The leaf characteristics were chosen based on previous studies on the variation of S. herbacea L., S. reticulata L. and Dryas octopetala L. (Marcysiak, 2012a, 2012b, 2014) and from diagnoses of $S$. retusa group taxa (Pawłowski, 1956; Rechinger, 1957, 1974; Dostál, 1989; Koblížek, 2006). The measurement procedure follows those described by Jasińska et al. (2015) with implementation of WinFolia Pro 2003 (Regent Instruments Inc.) software. 


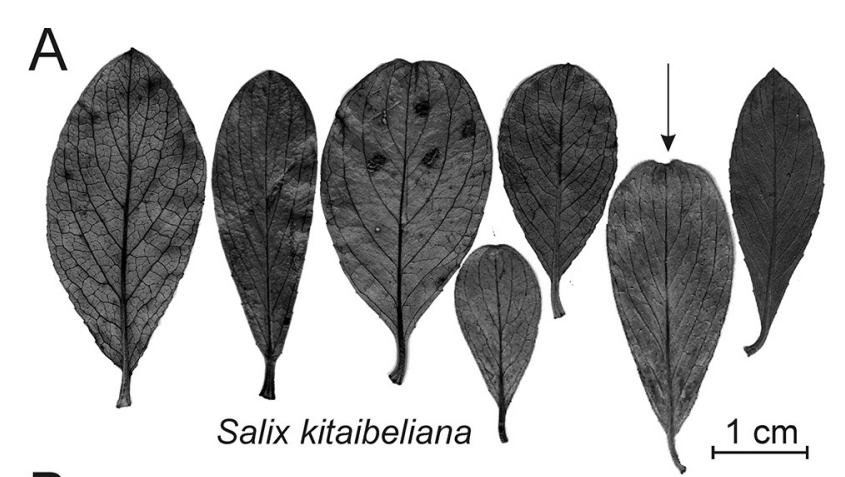

B

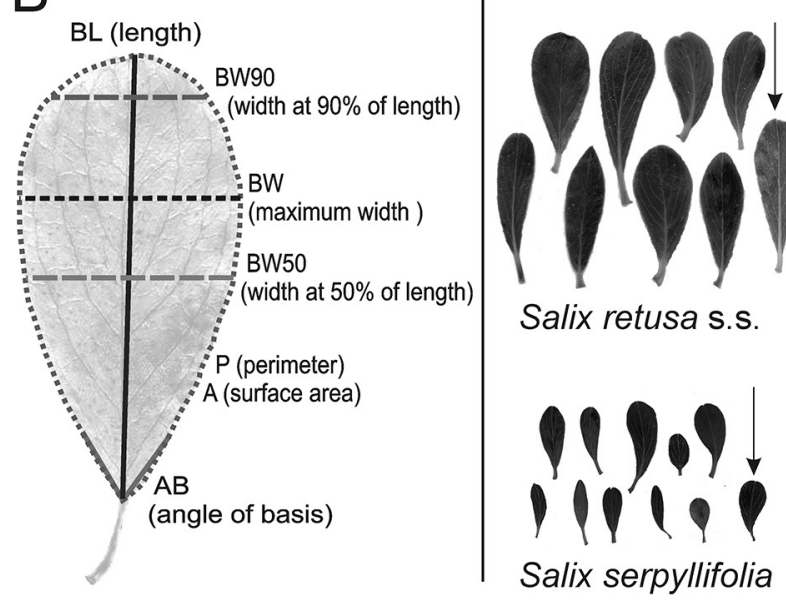

Fig. 1. A: examples of leaves of three willow taxa from Salix retusa group (arrows point to leaves close to average sizes); B: measured leaf characteristics

\section{Statistical analyses}

The frequency distribution of leaf characteristics values was verified using frequency histograms and the Shapiro-Wilk tests. To assess the possibility of parametric statistical test usage, the homoscedasticity of variances was verified by Brown-Forsythe test (Sokal \& Rohlf, 2003). The data were standardised before further analyses to avoid the possible influence of variation resulting from the different types of characteristics (Sokal \& Rohlf, 2003). For the statistical analyses, each individual was represented by an average of measurements of five leaves, and each population was represented by the average of all individuals.

The influence of particular characteristics on relationships among populations and the level of population differentiation was evaluated by implementation of principal component analysis (PCA) and Ward's agglomeration method based on Euclidean and Mahalanobis distances. These multivariate analyses were used to verify to which number of main clusters of populations, and subsequently of individuals, all data would be grouped and to which extent the populations/individuals would fit into taxonomic groups. The relationships among populations and individuals were illustrated on the scatter-plots of PCA, while clustering on dendrograms. A $K$-means cluster analysis ( $K$-MCA) was performed as a supplementation of the agglomeration on the closest Euclidean and Mahalanobis distances. These analyses detected the number of $K$-clusters, which optimally illustrated the differentiation between populations. To determine the optimal $K$ number, a scree plot was used with $\Delta \mathrm{d}$ value minimisation, when the succeeding nodes of agglomeration were added. Afterwards, a classification matrix was calculated to show the percentage of individuals within each population that were properly included into a particular $K$ group (Sneath \& Sokal, 1973). The K-grouping was presented cartographically to show geographic differentiation of the $S$. retusa complex.

The arithmetic mean (M), the median (MED), standard deviation (D) and variation coefficient (V) were calculated separately for every population and for each group detected with multivariate analysis, afterward comprehended as S. retusa s.s., S. serpyllifolia and S. kitaibeliana, to determine their ranges of diversity. The level of statistical significance of the differences between the median values of particular characteristics between taxa was verified using the Kruskal-Wallis test for data with skewed distribution and non-homoscedastic variances (Zar, 1999; Sokal \& Rohlf, 2003). The STATISTICA 13 (Copyright (C) 2016 Dell Inc.) and JMP 12.1 (Copyright (C) 2015 SAS Institute Inc.) software were used for statistical analyses.

\section{Results}

\section{Multivariate differentiation}

The distribution of the analysed leaf characteristics generally had skewed distribution and were characterised with non homoscedastic variances. These circumstances did not allow use of the parametric tests. For this reason, we showed the medians of measurements beside the arithmetic means, we used PCA analysis for grouping the populations, and the Kruskal-Wallis test to verify the significance of differences between groups.

PCA divided all compared populations into three groups in the space between the three first canonical variables, which accounted for nearly $98 \%$ of the total variation (Fig. 2. 1-2). The right group was formed by populations sampled as S. serpyllifolia in the Alps, which differed from the central one, the S. retusa s.s. from the Pyrenees, Alps, Apennines, Balkans and the East and South Carpathians. The populations sampled as $S$. retusa s.l. in the Tatra Mountains all formed the left separate group, which was not as compact as the two previous ones (Fig. 


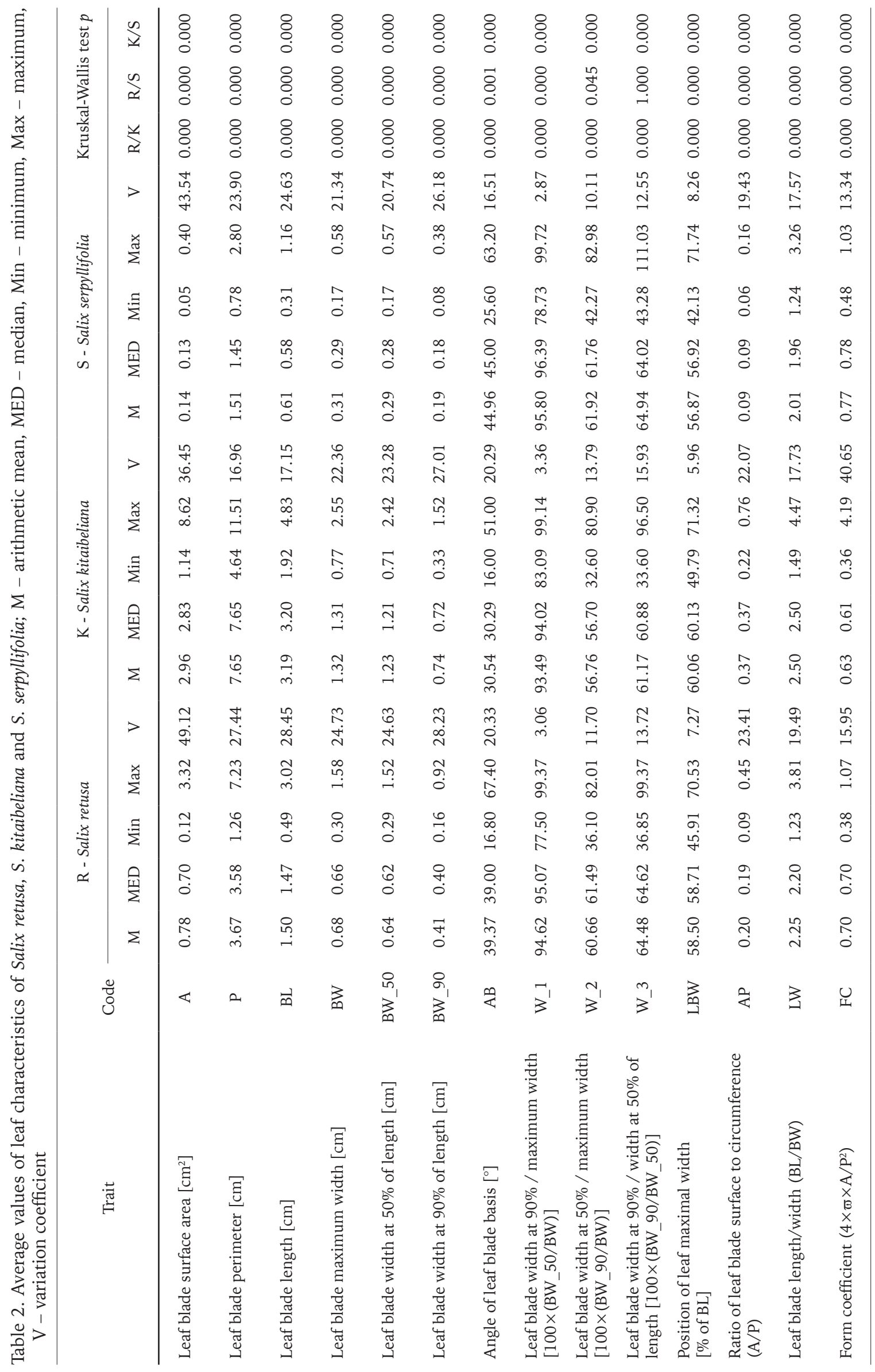



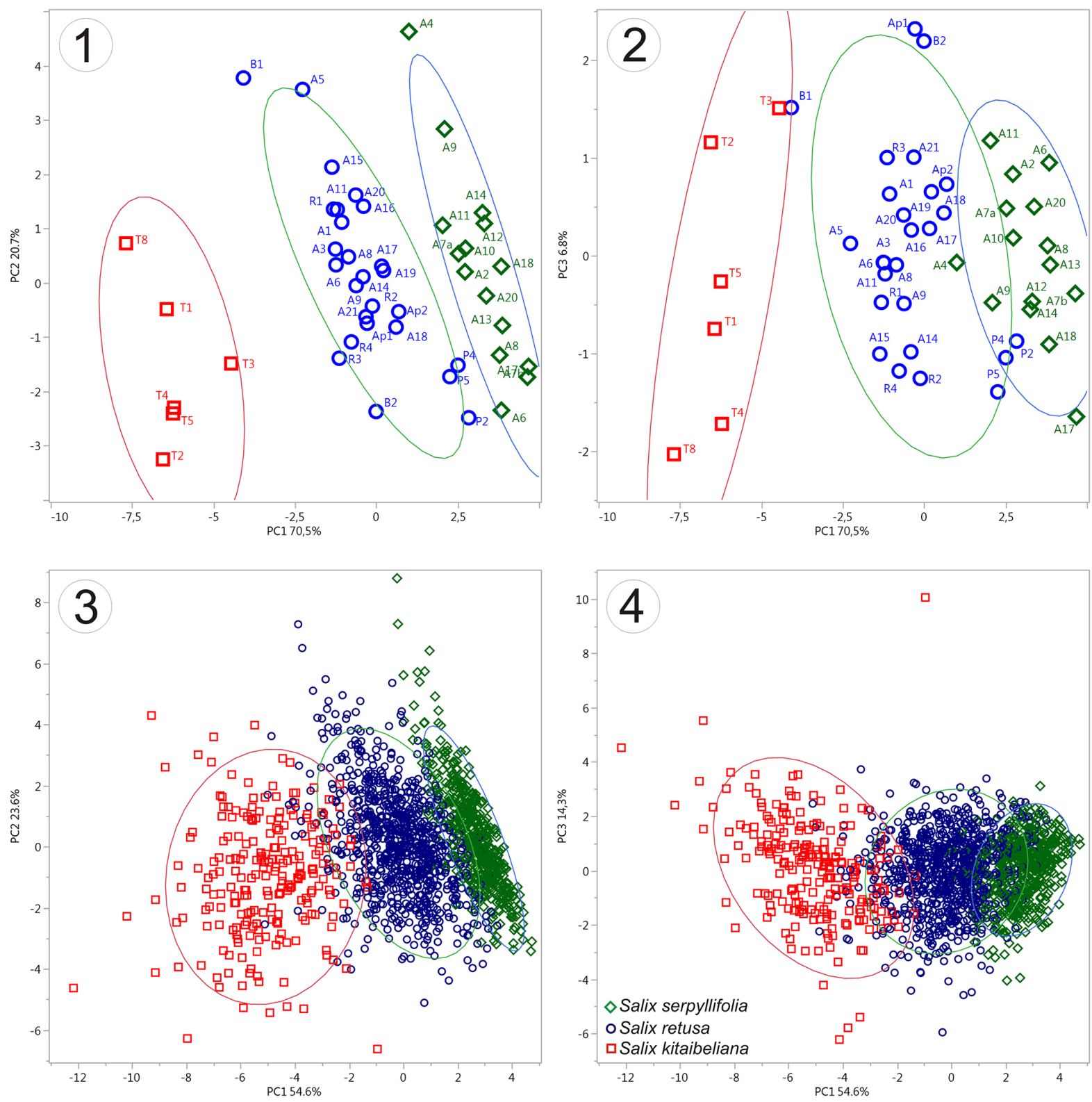

Fig. 2. Morphological subdivision of Salix retusa complex into three groups: S. retusa s.s., S. serpyllifolia and S. kitaibeliana: results of PCA for populations (1-2) and for individuals (3-4); lines indicate $90 \%$ confidence intervals for each group of individuals (codes of populations as in Table 1)

2. 1-2). We provisionally named this group S. kitaibeliana, because the values of dimensional characters (A, P, BL, BW) were the highest when compared to the other populations. The first canonical variable was determined mostly by the leaf dimensional characters (A, P, BL, BW, BW50 and BW90) and position of the leaf maximal width (LBW), the second by ratios of leaf widths (W2 and W3) and leaf area to the circumference (AP), while the third by the ratio of leaf length to width (LW).

The result of PCA conducted on the level of individuals also showed three clouds of individuals representing S. serpyllifolia, S. retusa s.s. and S. kitaibeliana, but very close to each other and partly intermingled. Surprisingly, the individuals of S. serpyllifolia substantially entered the $95 \%$ confidence interval of $S$. retusa s.s., while individuals of $S$. kitaibeliana intermingled with those of $S$. retusa s.s. to a lesser degree (Fig. 2. 3-4). The differences between taxa are determined mostly by the first canonical variable, while the second and third canonical variables showed differences between individuals within a taxa.

The clustering on the shortest Euclidean distances between populations also showed differentiation of populations to the three main groups. The populations of S. retusa s.s. sampled in the Alps, Apennines, Balkans and East and South Carpathians formed one cluster. Within this group, populations from different geographic regions were intermingled and did not reveal any geographic pattern of differentiation 


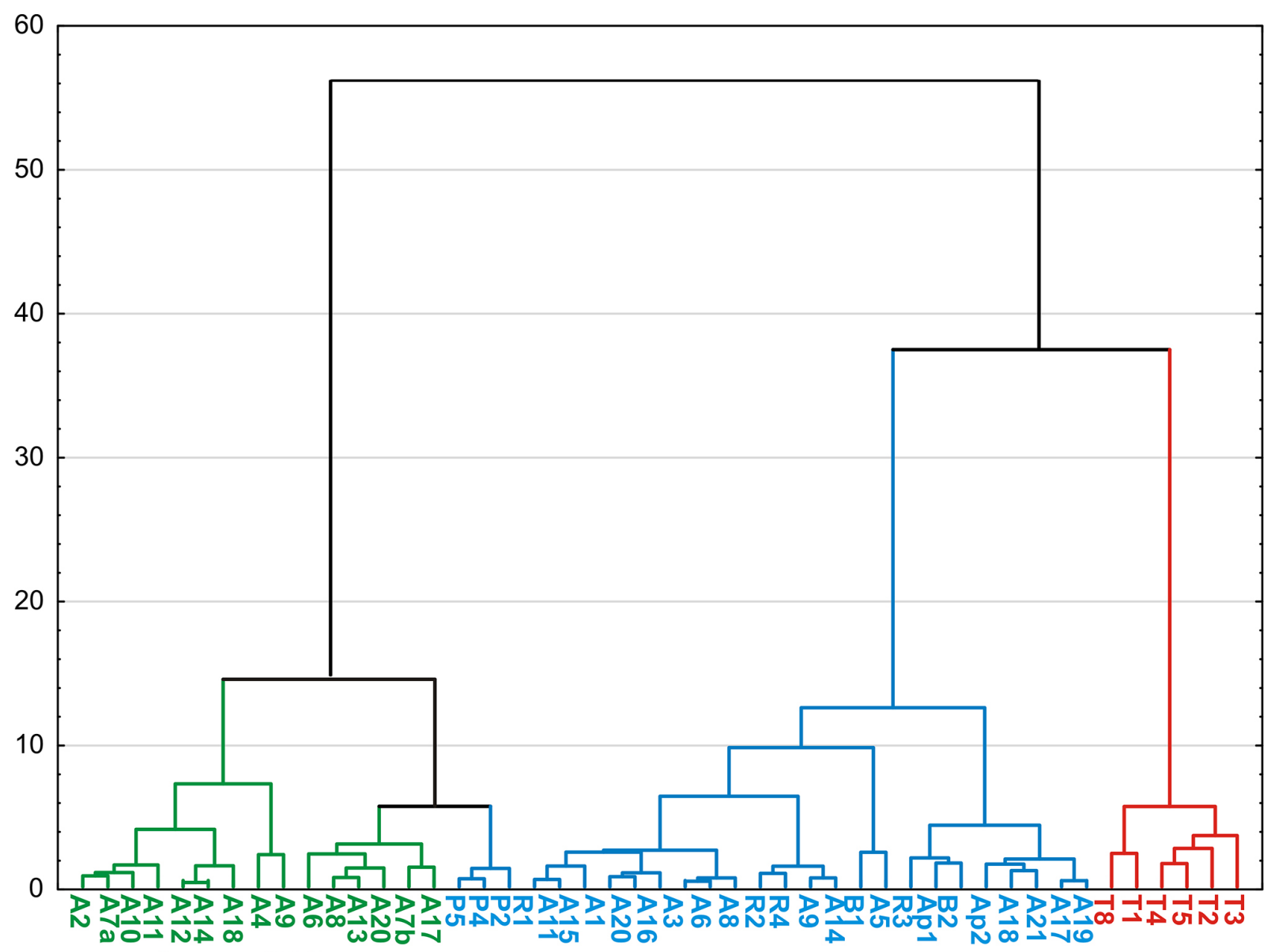

S. serpyllifolia

S. retusa s.s.

S. kitaibeliana

Fig. 3. Dendrogram constructed on Euclidean shortest distances between populations using Ward's method (populations codes as in Table 1)

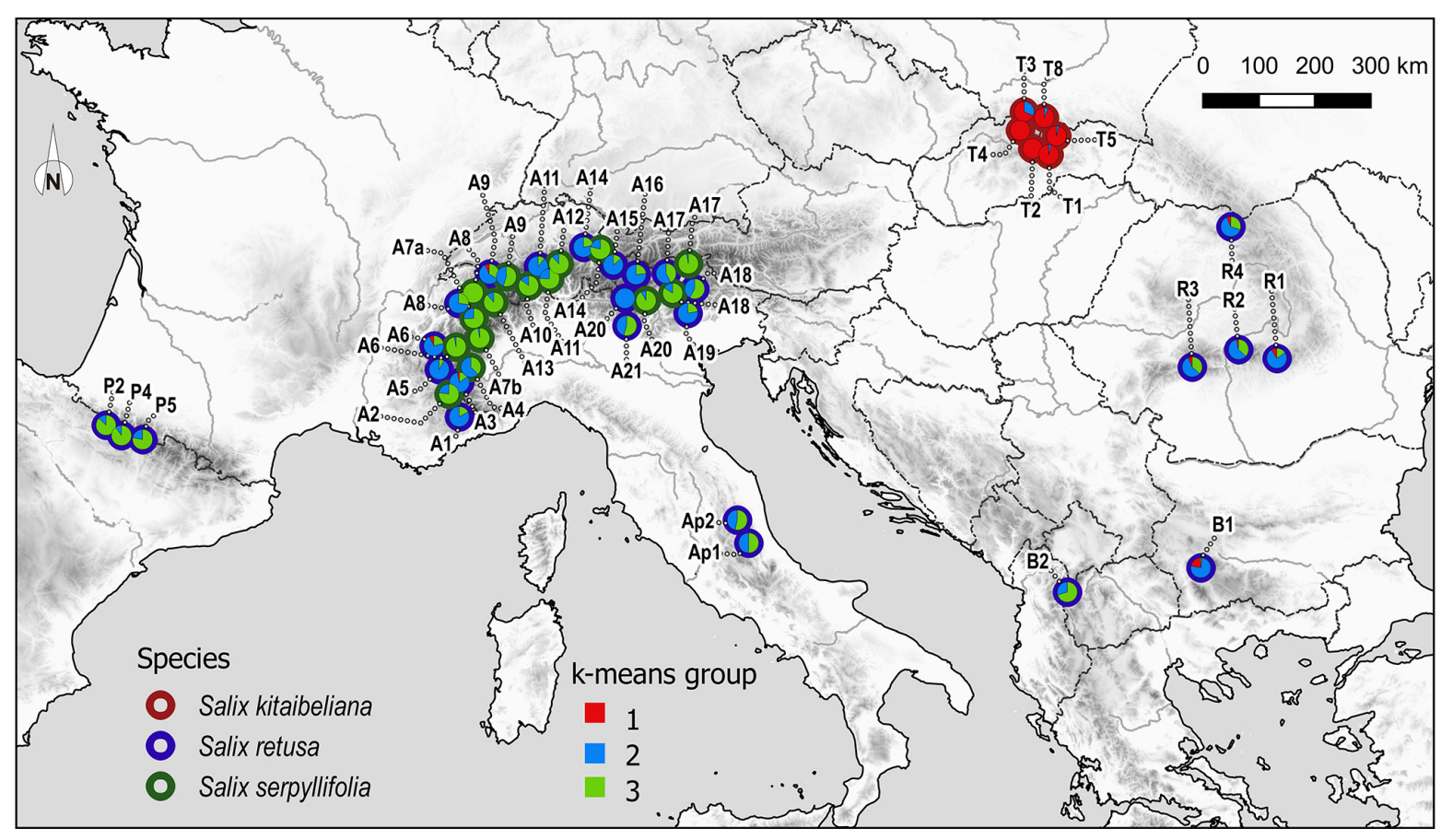

Fig. 4. Geographic distribution of three groups of populations of the Salix retusa complex detected with K-means clustering. Symbols indicate the percentage proportions of individuals included in one of the three $K$-groups within every sampled population 
(Fig. 3). The second cluster, provisionally named S. kitaibeliana, formed populations from the Tatra Mountains. The third cluster was formed by populations of $S$. serpyllifolia, but also included three Pyrenean populations of $S$. retusa s.s. as a separate sub-cluster. Population differentiation on the basis of the Mahalanobis distances was similar to that found on the basis of Euclidean distances (data not shown).

The three groups of populations detected by PCA and confirmed in the clustering were also detected as optimal when the K-grouping method was applied. However, the classification matrix showed that most of the analysed populations included individuals from two or even three groups (Fig. 4). Surprisingly, the individuals classified as S. serpyllifolia prevailed in populations from the Pyrenees and individuals resembling S. kitaibeliana were detected in the Balkan and Alpine populations.

The differences between $S$. retusa s.l. (including S. kitaibeliana) populations sampled from calcareous versus siliceous sites have not been detected. The statistically significant differences were found only between populations sampled from the siliceous rocks in the Tatra Mountains and the other populations in the entire data set of S. retusa s.s.

\section{Differentiation of characteristics}

The most variable characteristics were the area of leaf blade (A) and the leaf form coefficient (FC), both with variation coefficients higher than $40 \%$ in S. retusa s.s. and S. serpyllifolia (A), and in S. kitaibeliana (FC) (Table 2). The average of variation coefficients for $S$. retusa s.s., S. kitaibeliana and S. serpyllifolia were $21.2,20.2$ and $18.6 \%$, respectively (Table $2)$. The dimensional characteristics were statistically significantly correlated $(\mathrm{p} \leq 0.01)$, with $\mathrm{r}=0.90$ or higher.

Every characteristic, except for the ratio of leaf blade width at $90 \%$ to width at $50 \%$ of the length (W 3), and leaf blade width at the mid-length to maximal width (W_2) differed significantly $(\mathrm{p} \leq 0.01)$ between possible combinations of the three taxa (Table 2). W 2 differed between S. retusa s.s. and S. kitaibeliana $(\overline{\mathrm{p}} \leq 0.01)$, between $S$. kitaibeliana and $S$. serpyllifolia $(\mathrm{p} \leq 0.01)$, and between $S$. retusa s.s. and S. serpyllifolia $(\mathrm{p} \leq 0.05)$. W 3 did not differ between S. retusa s.s. and S. serpyllifolia. Despite significant differences between average values of dimensional features, the variation ranges of shape characteristics overlapped significantly (Table 2).

\section{Discussion}

All 14 characteristics describing leaf morphology separated S. retusa s.s. from S. kitaibeliana, and
S. kitaibeliana from S. serpyllifolia, while 13 characteristics distinguished S. retusa s.s. from S. serpyllifolia. These results are consistent with the accepted taxonomic classification of S. retusa s.s. and S. serpyllifolia (e.g. Neumann, 1981; Chmelař et al., 1979; Dostál, 1988; Martini \& Paiero, 1988; Skvortsov, 1999; Hörandl et al., 2002). The very high level of distinction of $S$. kitaibeliana from $S$. retusa s.s. found in the present study (Table 2, Figs. 1 and 2) confirms its separate taxonomic status proposed at least for the Tatra Mountains (Pawłowski, 1956; Rechinger, 1957, 1964; Dostál, 1989; Koblížek, 2006). The combination of dimensional and shape characteristics of leaves allowed differentiation with a high probability between S. retusa s.s., S. serpyllifolia and S. kitaibeliana, despite partly overlapping variation ranges of particular characteristics among studied taxa (Table 2).

The leaves of $S$. retusa s.s. were found as $0.5-3.0$ $\mathrm{cm}$ long (1.5 cm on average) and $0.3-1.5 \mathrm{~cm}$ wide ( $0.7 \mathrm{~cm}$ on average), while those of $S$. serpyllifolia were $0.3-1.2 \mathrm{~cm}$ long $(0.6 \mathrm{~cm}$ on average) and $0.2-0.6 \mathrm{~cm}$ wide $(0.3 \mathrm{~cm}$ on average) (Fig. $1 \mathrm{~A})$. These data correspond well with those reported in the literature (compare Tables 2 and 3). It should be noted, however, that average values of BL and MW reported from the Tatra Mountains (e.g. Zapałowicz, 1908; Szafer, 1921; Pawłowski, 1956; Kobližek, 2006) were much higher than from other parts of the geographic range of S. retusa s.s. (Table 3). The close systematic relationships between taxa of the $S$. retusa complex have been stressed by Rechinger (1957, 1964), who distinguished S. retusa, S. serpyllifolia and S. kitaibeliana. The lack of differences between S. retusa s.s. and S. kitaibeliana has been underlined by Skvortsov (1999). This could result from the limited number of herbarium materials from the Tatra Mountains that were accessible for him. The data presented here result from analyses of a large number of individuals and thus, for the first time, give exact and reliable information on not only commonly reported leaf dimensional characteristics, the most frequently used of which is length and width (BL and BW, respectively in Table 2), but also five other morphological traits, not reported until now. From the 224 individuals of $S$. retusa s.l. sampled in the Tatra Mountains, 210 had leaf characteristics that classified them as S. kitaibeliana (Fig. 4).

Every population sampled from the Tatra Mountains had leaf length and widths twice as high as the average found for all populations of S. retusa s.s. (Table 2). This finding could be interpreted as resulting from the separate geographic position within the geographic range of S. retusa s.l., but also as having taxonomic status. Unfortunately, the populations from the Tatra Mountains have only been sampled from siliceous substrata (Table 1), which was designated as typical sites of S. kitaibeliana (Pawłowski, 1956, 1972; Zieliński, 1977; Kobližek, 2006). Nevertheless, the 


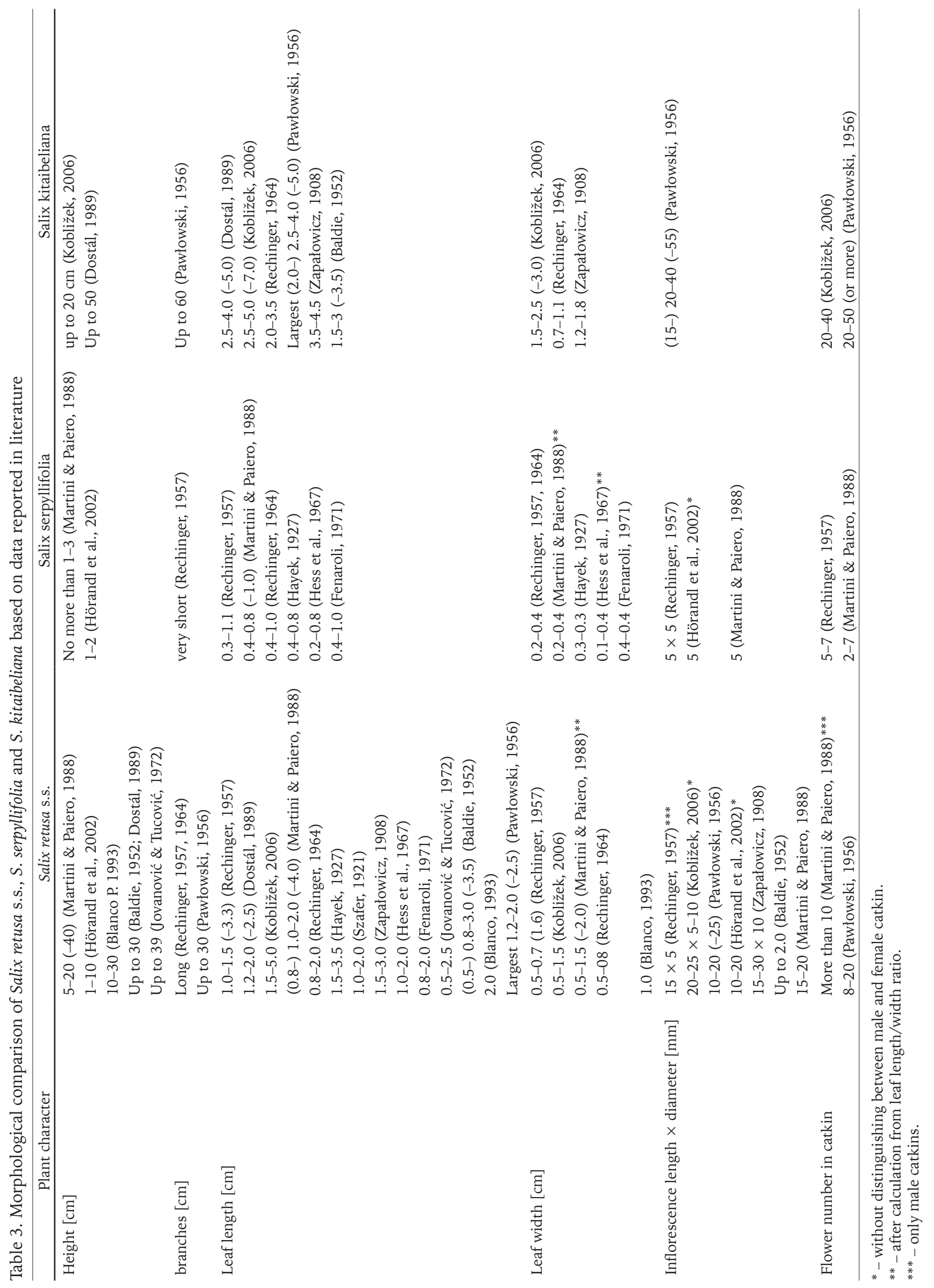


Romanian populations (Eastern and Southern Carpathians) growing on acid rocks displayed leaf characteristics mostly similar to $S$. retusa s.s. It is noteworthy, that five of the six analysed populations from the Tatra Mountains contained only the typical $S$. kitaibeliana individuals, or included single individuals resembling S. retusa s.s. (Fig. 4). Populations from the Eastern and Southern Carpathian Mountains (Romania) and Rila (Bulgaria) included some amount of $S$. kitaibeliana individuals. This is similar to that found in subalpine Pinus mugo Turra populations, where some individuals typical of the Tatra Mountains were detected in populations from the East and South Carpathians and Bulgarian Mountains (Boratyńska et al., 2015; Dzialuk et al., 2016).

The differences in leaf traits between $S$. retusa s.s., S. serpyllifolia and S. kitaibeliana have mostly been of quantitative nature. This has been stressed by most authors (e.g. Pawłowski, 1956, Rechinger, 1957, 1964; Kobližek, 2006). For this reason, all three taxa were grouped as S. retusa (Rechinger, 1964). Our results support this opinion.

The marginal populations sampled in the Apennines and in the Albanian Korab Massif contained an amount of individuals classified as S. serpyllifolia (Fig. 4), i.e. with smaller leaves than are found for typical $S$. retusa. This could be a result of long isolation of marginal populations and from more xeric conditions. This may be confirmed by the fact that some individuals from these populations growing in moist conditions developed longer shoots and larger leaves (Supplementary Fig. 4). The influence of habitat conditions on the growth of these willows should be verified in the additional study.

A further new finding of the present study is the different position of $S$. retusa from the Western Pyrenees. The three populations from this mountain range appeared to be different from the Alpine and Carpathian populations and were even grouped together with the Alpine population of S. serpyllifolia (Fig. 3). The result of the PCA conducted on the level of population (Fig. 2) showed that the Pyrenean populations were placed between $S$. retusa s.s. and S. serpyllifolia. This was also confirmed by the Kruskal-Wallis test (data not included) performed for three groups of populations (S. serpyllifolia, S. retusa s.s. excluding Pyrenees, and Pyrenean populations of S. retusa), where populations from the Pyrenees differed significantly both from S. serpyllifolia (13 characteristics) and S. retusa s.s. (all characteristics). The Pyrenean populations were characterised by intermediate size of leaves (Supplementary Figs 5-6) and more rounded leaf blades (Supplementary Figs 7-8). These results may indicate a separate taxonomical status of Pyrenean populations of $S$. retusa, but this should be confirmed in a deeper study.

\section{Conclusion}

The results support close taxonomic relationships, but also the separate status of S. retusa, S. serpyllifolia and S. kitaibeliana.

\section{Acknowledgments}

This study was financially supported by the Polish National Science Centre (NCN), project no. N N303 798240. We would like to thank P. Górski and A. Indreica for their help in material collection, K. Boratyńska - for her statistical consultations, J. Zieliński for sharing his knowledge on systematics of the genus Salix, S. García Álvarez and anonymous reviewer - for valuable comments, and J. Janicka, A. Kaczmarek, W. Kolberg, and M. Łuczak - for technical assistance.

\section{References}

Baldie A (1952) Salicaceae: Flora Republicii Populare Romane, vol. 1 (ed. by T Săvulescu) Academia Republicii Populare Române, pp. 265-322.

Blanco P (1993) Salix L.: Flora Iberica, vol. 3 (ed. by S Castroviejo, C Aedo, S Cirujano, M Laínc, P Montserrat, R Morales, F Muñoz Garmendia, C Navarro, J Paiva \& C Soriano) Madrid: Real Jardín Botánico, C.S.I.C., pp. 477-517.

Boratyńska K, Jasińska AK \& Boratyński A (2015) Taxonomic and geographic differentiation of Pinus mugo complex on the needle characteristics. Systematics and Biodiversity 13: 581-595.

Chmelař J, Meusel W, Lattke H \& Hammerling H-J (1979) Die weiden Europas: die gattung Salix. 2 ed. A. Ziemsen Verlag, Wittenberg Lutherstadt.

Danilik IM (2009) Salix retusa L.: Chervona kniga Ukrainy (ed. by YP Didukh) Kyiv, Globalkonsalting, p. 587.

Dostál J (1989) Nová květena ČSSR, 1. Academia, Praha.

Dzialuk A, Boratyńska K, Romo A \& Boratyński A (2016) Taxonomic and geographic variation of the Pinus mugo complex on chloroplast microsatellite markers. Systematics and Biodiversity. doi:10.108 0/14772000.2016.1257518.

Fenaroli L (1971) Flora delle Alpi. 2nd ed. Aldo Martello, Milano.

Hardig TM, Brunsfeld SJ, Fritz RS, Morgan M \& Orians CM (2000) Morphological and molecular evidence for hybridization and introgression in a willow ( $\mathrm{Sa}$ lix) hybrid zone. Molecular Ecology 9: 9-24.

Hayek A (1927) Prodromus florae peninsulae Balkanicae, 1. Repertorium speciorum novorum regni vegetabilis, Beihefte 30.1.

Hess HE, Landolt E \& Hirzel R (1967) Flora der Schweiz, 1. Birkhäser, Basel und Stuttgart. 
Horvat I, Glavač V \& Ellenberg E (1984) Vegetation Südeuropas. Geobotanica Selecta 4. G. Fischer, Stuttgart.

Hörandl E, Florineth F \& Hadacek F (2002) Weiden in Österreich und angrenzenden gebieten. Universität für Bodenkultur, Wien.

Jalas J \& Suominen J (1976) Atlas florae Europaeae: distribution of vascular plants in Europe Vol. 3 Salicaceae to Balanophoraceae. The Committee for Mapping the Flora of Europe and Societas Biologica Fennica Vanamo, Helsinki.

Jasińska AK, Rucińska B, Kozlowski G, Bétrisey S, Safarov H, Boratyńska K \& Boratyński A (2015) Morphological differentiation of leaves in the relict tree Zelkova carpinifolia (Ulmaceae). Dendrobiology 74: 109-122.

Jovanović B \& Tucović A (1972) Salicaceae: Flore de la Republique Socialiste de Serbie, 3 (ed. by M Josifović) Academie Serbe des Sciences et des Arts, Beograd, pp. 405-457.

Koblížek J (2006) Salix L.: Flóra Slovenska, v. 3 (ed. by K Goliašová \& E Michalková) Veda, Bratislava, pp. 209-290.

Marcysiak K (2012a) Variation of leaf shape of Salix herbacea in Europe. Plant Systematics and Evolution 298: 1597-1607.

Marcysiak K (2012b) Diversity of Salix reticulata L. (Salicaceae) leaf traits in Europe and its relation to geographical position. Plant Biosystems 146, Suppl. 1: 101-111.

Marcysiak K (2014) Geographical differentiation of Dryas octopetala in Europe based on morphological features. Dendrobiology 72: 113-123.

Martini F \& Paiero P (1988) I salici d'Italia: Guida al riconoscimento e all'utilizzazione pratica. Trieste, Edizioni LINT.

Mirek Z, Piękoś-Mirkowa H, Zając A \& Zając M (2002) Flowering plants and pteridophytes of Poland. A checklist W. Szafer Institute of Botany, Polish Academy of Sciences, Kraków.

Mosca E, Eckert AJ, Di Pierro EA, Rocchini D, La Porta N, Belletti P \& Neale DB (2012) The geographical and environmental determinants of genetic diversity for four alpine conifers of the European Alps. Molecular Ecology 21: 5530-5545. doi: 10.1111/mec.12043.

Nagy L, Grabherr G, Körner Ch \& Thompson DBA (2003) Alpine biodiversity in Europe. Berlin Heidelberg, Springer.

Neumann A (1981) Die mitteleuropäischen Salix Arten. Österreich. Agrarverlag, Wien.

Ozenda P (1988) Die Vegetation der Alpen im europäischen Gebirgsraum. Elsevier, München.

Ozenda P \& Borel J-L (2003) The Alpine Vegetation of the Alps: Alpine biodiversity in Europe (ed. by L Nagy, G Grabherr, Ch Körner \& DBA Thomp- son) Ecological Studies, Springer, Berlin, Heidelberg, pp. 53-64.

Pawłowski B (1956) Flora Tatr. Rośliny naczyniowe. Vol. 1. Państwowe Wydawnictwo Naukowe, Warszawa.

Pawłowski B (1972) Szata roślina gór Polski: Szata roślinna Polski, 2 (ed. by W Szafer \& K Zarzycki) Polskie Wydawnictwo Naukowe, Warszawa, pp. 189-250.

Rechinger KH (1957) Salix L.: Illustrierte flora von Mitteleuropa Bd. 3.1. 2nd ed. (G Hegi) C. Hanser, München, pp. 44-135.

Rechinger KH (1964) Salix L.: Flora Europaea 1 (ed. by TG Tutin, VH Heywood, NA Burges, DH Valentine, SM Walters \& DA Webb) University Press, Cambridge, pp. 45-54.

Ronikier M (2011) Biogeography of high-mountain plants in the Carpathians: An emerging phylogeographical perspective. Taxon 60: 373-389.

Skvortsov AK (1999) Willows of Russia and adjacent countries. Joensuu University Press, Joensuu, Finland.

Sneath PH \& Sokal RR (1973) Numerical taxonomy: the principles and practice of numerical classification. W. H. Freeman, San Francisco, CA.

Sokal RR \& Rohlf FJ (2003) Biometry. The principles and practice of statistics in biological research. 3rd ed. W. H. Freeman and Co., New York.

Szafer W (1921) Salicales: Flora polska, 2 (ed. by W Szafer) Akademia Umiejętności, Kraków, pp. 24-47.

Thiel-Egenter C, Alvarez N, Holderegger R, Tribsch A, Englisch T, Wohlgemuth T, Coli L, Gaudeul M, Gielly L, Jogan N, Linder HP, Negrini R, Niklfeld $\mathrm{H}$, Pellecchia M, Rioux D, Schönswetter P, Taberlet $\mathrm{P}$, van Loo $\mathrm{M}$, Winkler $\mathrm{M}$, IntraBioDiv Consortium \& Gugerli F (2011) Break zones in the distributions of alleles and species in alpine plants. Journal of Biogeography 38: 772-782. doi:10.1111/j.1365-2699.2010.02441.x.

Villar PL, Sesé JA, Franco JAS \& Ferrández JV (1997) Atlas de la flora del Pirineo Aragonés. Vol. 1. Consejo de Protección de la Naturaleza de Aragón, Huesca.

Zając M \& Zając A (2009) The geographical elements of the native flora of Poland. Laboratory of Computer Chorology, Institute of Botany, Jagiellonian University, Kraków.

Zapałowicz H (1908) Conspectus florae Galiciae criticus. Akademia Umiejętności, Kraków.

Zar JH (1999) Biostatistical analysis. Prentice Hall, New Jersey.

Zieliński J (1977) Salix retusa L.: Atlas of distribution of trees and shrubs in Poland, vol. 22 (ed. by K Browicz) pp. 7-9, 41-42. 